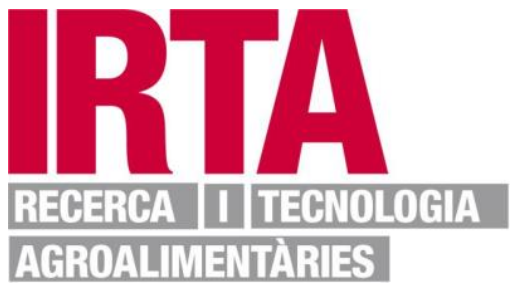

This document is a postprint version of an article published in Scientia Horticulturae (C) Elsevier after peer review. To access the final edited and published work see_https://doi.org/10.1016/i.scienta.2019.03.031

Document downloaded from: 


\section{Post Petal Fall Applications of Gibberellins 2 Improve Fruit Set on Pear}

3 Jaume Lordan ${ }^{1, *}$, Pere Vilardell ${ }^{2}$, Miquel Peris ${ }^{1}$, Estanis Torres ${ }^{1}$, Simó

4 Alegre $^{1}$, and Luis Asín ${ }^{1}$

$5{ }^{I}$ IRTA Fruitcentre, PCiTAL, Park of Gardeny, Fruitcentre Building, 25003 Lleida,

6 Spain;

7 IRTA Mas Badia Field Station, La Tallada de l'Empordà, Girona, 17134, Spain

8 *Corresponding author: E-mail address: Jaume.lordan@irta.cat 


\section{Post Petal Fall Applications of Gibberellins 2 Improve Fruit Set on Pear}

\section{Abstract}

4 Commercial pear production has become increasingly difficult over the last decade, with

5 low fruit set being one of the main factors leading to poor yield of pear orchards. The use

6 of gibberellins to increase fruit set has been widely reported, but in most of the cases these

7 applications are made at full bloom or right after a spring frost has occurred. However,

8 the increase in fruit set due to early applications of gibberellins such as at full bloom is

9 often lost at June drop. Aim of this study was to assess dose and timing of different

10 gibberellin applications made after petal fall to improve the final fruit set in pear orchards.

11 Four experiments were conducted during four years (2010-2013) in mature pear orchards

12 with 'Conference' as the scion cultivar. Fruit set and yield were increased when

13 gibberellins were applied after petal fall, with a positive relationship with dose.

14 Applications of $\mathrm{GA}_{4+7}+\mathrm{BA}$ tended to promote higher fruit set and yield than $\mathrm{GA}_{3}$, and in

15 addition, they were less dependent to the moment of application. GA4+7 + BA showed an

16 additive effect when performing multiple applications. Return bloom was slightly

17 affected when gibberellins were applied after petal fall. The strategy that showed a better

18 behavior to increase fruit set was $\mathrm{GA}_{4+7}+\mathrm{BA}$ at $500 \mathrm{~mL} \cdot \mathrm{ha}^{-1}$ at $\mathrm{H}+14$, which coincides with

19 the weeks of the natural fruit drop.

20 Keywords: Abscission; fruit weight; $\mathrm{GA}_{3}, \mathrm{GA}_{4+7}$, Pyrus communis; return bloom; yield

\section{Introduction}

22 Pear (Pyrus spp.) is widely cultivated around the world, and can be consumed both fresh

23 and dry (Ceylan et al., 2018; Çolak, 2018; Okatan et al., 2017). Commercial pear 
production has become increasingly difficult over the last decade, with low fruit set being one of the main factors leading to poor yield of pear orchards (Webster, 2002). Furthermore, even when fruit set seems to be good through self-pollination, most of the fruitlets can abscise shortly after setting (Warnier, 2000). In addition, fruitlet abscission on young trees is particularly severe (Webster, 2002). Italy and Spain are the most important pear (Pyrus communis L.) producing countries in Europe (Deckers and 30 Schoofs, 2008). While 'Conference' is the second most important cultivar grown in Italy 31 (Deckers and Schoofs, 2008); it is the most important cultivar grown in Spain (Iglesias and Casals, 2013), and in Northern Europe, with $80 \%$ of the acreage in the Netherlands (Heijerman et al., 2015), and 85\% in Belgium (Vercammen, 2014). The achieved yield of pear orchards in Spain tends to be significantly lower than in other countries such as Belgium and the Netherlands, and it is assumed that this is caused by a poor fruit set. Competition for resources between fruitlets and the actively growing shoots has been suggested to induce fruitlet abscission (Webster, 2002). In situations of poor setting, the first approach that is usually adopted is the use of plant growth regulators (PGRs). The options are diverse, and include gibberellins ( $\mathrm{GA}_{3}, \mathrm{GA}_{4+7}$ formulates), auxin-like substances (IAA, NAA and NAAm), cytokinins (zeatin-related and adenine-related molecules, kinetin and 6-BA), ethylene inhibitors (aminoethoxyvinilglycine), growth control regulators (prohexadione-Ca), and even the use of anti-gibberellin formulates (Carra et al., 2018; Costa, 2017; Pasa et al., 2017a; Vercammen et al., 2015; Webster, 44 2002).

The use of gibberellins to increase fruit set has been widely reported, but in most of the cases these applications are made at full bloom or right after a spring frost has occurred

47 (Costa, 2017; Deckers and Daemen, 1996; Deckers and Schoofs, 2000; Lafer, 2008; Ozturk and Askin, 2015; Pasa et al., 2017b; Silva et al., 2010; Yarushnykov and Blanke, 
2007). However, the increase in fruit set due to early applications of gibberellins such as

50 at full bloom is often lost at June drop (Vercammen et al., 2015).

51 The goal of this study was to assess dose and timing of different gibberellin applications made after petal fall to improve the final fruit set in pear orchards.

\section{Materials and methods}

\section{Experiments 1-3}

Three field trials were conducted during three years (2010-2012) at the experimental station of IRTA (Institute of Research and Technology, Food and Agriculture) in Gimenells, Spain $\left(41^{\circ} 39^{\prime} 22.25^{\prime \prime N} ; 0^{\circ} 23^{\prime} 25.37^{\prime \prime E}\right)$, where we compared different timing and dose applications of gibberellic acid (Arabelex $\mathrm{L}^{\circledR}, \mathrm{GA}_{3} 1.6 \%$, Aifar Agrochimica S.R.L., Genova, Italia) and benzyladenine (BA) plus $\mathrm{GA}_{4+7}\left(\right.$ Promalin $^{\circledR}$, a mixture of 1.9\% BA and $1.9 \% \mathrm{GA}_{4+7}$, Valent BioSciences LLC., Libertyville, IL, USA) to improve fruit set on pear trees. The experiments were conducted in a mature pear orchard planted in 1994 with 'Conference' as the scion cultivar grafted on Quince BA-29 rootstock. Planting distance was $4 \mathrm{~m} \times 1.5 \mathrm{~m}(1667$ trees/ha). The experiments were organized in a randomized complete block design with four replications, with each experimental unit being a section of four trees. For each replication data was collected on those two central trees that were more homogeneous and representative of each experimental unit. In year 1 (Experiment 1), treatments included $\mathrm{GA}_{3}$ at $1 \mathrm{~g}$ and $2 \mathrm{~g}$ of active ingredient per ha applied at petal fall $(\mathrm{H})$ plus 7,14 , and 21 days $(\mathrm{H}+7, \mathrm{H}+14, \mathrm{H}+21$, respectively) (Fleckinger, 1964) (Table 1). In year 2 (Experiment 2), treatments included $\mathrm{GA}_{3}$ at $1 \mathrm{~g}$ and $2 \mathrm{~g}$ of active ingredient per ha and $\operatorname{Promalin}^{\circledR}$ at $500 \mathrm{~mL} \cdot \mathrm{ha}^{-1}$ applied at $\mathrm{H}+7, \mathrm{H}+14$,

$71 \mathrm{H}+21, \mathrm{H}+7 \& \mathrm{H}+14, \mathrm{H}+14 \& \mathrm{H}+21$ (Table 1). In year 3 (Experiment 3), treatments included $\mathrm{GA}_{3}$ at $2 \mathrm{~g}$ of active ingredient per ha and Promalin ${ }^{\circledR}$ at $250 \mathrm{~mL} \cdot \mathrm{ha}^{-1}$ and 500 
$\mathrm{mL} \cdot \mathrm{ha}^{-1}$ applied at $\mathrm{H}+7, \mathrm{H}+14$, and $\mathrm{H}+21$ (Table 1 ). Control trees were not sprayed whatsoever.

\section{Experiment 4}

Four field trials were conducted in 2013 in four commercial orchards at Tornabous, Spain

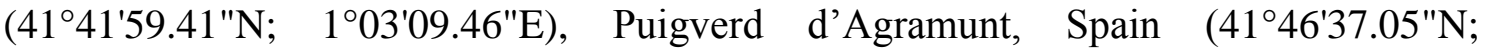

$\left.1^{\circ} 07^{\prime} 17.44^{\prime \prime E}\right)$, Bellpuig, Spain $\left(41^{\circ} 37^{\prime} 31.56 " \mathrm{~N} ; 1^{\circ} 00^{\prime} 43.02^{\prime \prime E}\right)$, and Castellnou de Seana,

Spain (41 $\left.38^{\prime} 52.74 " \mathrm{~N} ; 0^{\circ} 58^{\prime} 13.55^{\prime \prime} \mathrm{E}\right)$, where we compared applications of benzyladenine

(BA) plus $\mathrm{GA}_{4+7}\left(\operatorname{Promalin}^{\circledR}\right.$, a mixture of $1.9 \%$ BA and $1.9 \% \mathrm{GA}_{4+7}$, Valent BioSciences

LLC., Libertyville, IL, USA) at $500 \mathrm{~mL} \cdot \mathrm{ha}^{-1}$ applied at $\mathrm{H}+7, \mathrm{H}+14, \mathrm{H}+21$, and $\mathrm{H}+7$ \&

$\mathrm{H}+14 \& \mathrm{H}+21$ (Table 1). The experiments were conducted in mature pear orchards with

83 'Conference' as the scion cultivar grafted on Quince BA-29 rootstock. Tornabous was planted in 1998 at $4 \mathrm{~m} \times 1.2 \mathrm{~m}$, Puigverd d'Agramunt was planted in 2006 at $4 \mathrm{~m} \times 1.1$ $\mathrm{m}$, Bellpuig was planted in 1998 at $4 \mathrm{~m} \times 1.5 \mathrm{~m}$, and Castellnou de Seana was planted in 2001 at $3.8 \mathrm{~m} \times 1.5 \mathrm{~m}$. The experiments were organized in a randomized complete block design with four replications, with each experimental unit being a section of four trees. For each replication data was collected on those two central trees that were more homogeneous and representative of each experimental unit. Control trees were not sprayed whatsoever.

\section{PGR application and Data Collection}

All the chemical treatments were applied with a handgun sprayer until run-off.

93 The spray volumes were $1000 \mathrm{~L} \cdot \mathrm{ha}^{-1}$. Trees were drip-irrigated (climate is semi-arid 94 Mediterranean, with a mean annual rainfall of $350 \mathrm{~mm}$ ). Climatic variables such as maximum temperature $\left(\operatorname{Tmax},{ }^{\circ} \mathrm{C}\right)$, minimum temperature $\left(\mathrm{Tmin},{ }^{\circ} \mathrm{C}\right)$, and relative humidity (RH, \%) were obtained from the closest automatic weather station in Gimenells, 
97 Spain (Table 2). Plots were managed within IPM management according to industry

98 standards.

99 For each experiment, the following data was recorded for each single tree: (1) number of

100 flower clusters, (2) fruit number, (3) yield, and (4) return bloom.

101 Fruit set was calculated from the final number of fruit per tree and the initial number of

102 flower clusters per tree. All harvested fruit from each tree were graded for fruit weight

103 and caliper distribution by a weight sizer machine (MAF RODA Iberica, Alzira, Spain).

104 Return bloom was measured the following spring, by counting the total number of flower

105 clusters per tree.

\section{Data Analysis}

107 Response variables were modeled using linear mixed effect models. A first analysis was

108 carried out, then subsequent analyses were performed taking into account significance of

109 interactions. Mixed models including treatment as fixed factor and block as random factor

110 were built to separate treatment effects for flower number, fruit set, yield, fruit weight,

111 percentage of yield $>60 \mathrm{~mm}$, percentage of yield $>65 \mathrm{~mm}$, and return bloom. For all the

112 models, when the main effect (treatment) was significant, comparisons among treatments

113 were made by Tukey's HSD test at $P$ values $\leq 0.05$. Residual analysis (normal

114 distribution of residuals) was performed to insure that model assumptions were met. Data

115 were analyzed using the JMP statistical software package (Version 12; SAS Institute Inc., 116 Cary, NC).

\section{Results}

\section{Experiment 1}

119 The initial number of flower clusters per tree was very similar for all the trees, with no 
120 significant differences among treatments (Table 3). Fruit set was increased when

121 increasing the dose, and the highest values were when the application was made 14 days

122 after petal fall, followed by 7 days after, and the lowest value for 21 days after. The

123 highest fruit set was when $\mathrm{GA}_{3}$ was applied at $2 \mathrm{~g} \cdot \mathrm{ha}^{-1}$ at 14 days and 7 days after petal

124 fall (69 and 60, respectively), followed by $1 \mathrm{~g} \cdot \mathrm{ha}^{-1}$ at +14 days (58), and +7 days (44).

125 The lowest values were for 21 days after petal fall at either $1 \mathrm{~g} \cdot \mathrm{ha}^{-1}$ or $2 \mathrm{~g} \cdot \mathrm{ha}^{-1}$ (42 or 40 ,

126 respectively), and for untreated control trees (40).

127 Yield was similarly affected as fruit set, highest yields were for highest dose and when

128 was applied at 14 or 7 days after petal fall. The highest yield was for $\mathrm{GA}_{3}$ applied at 2

$129 \mathrm{~g} \cdot \mathrm{ha}^{-1}$ at 14 days after petal fall $(30 \mathrm{~kg})$, followed by $2 \mathrm{~g} \cdot \mathrm{ha}^{-1}$ at $\mathrm{H}+7(27 \mathrm{~kg})$, and $1 \mathrm{~g} \cdot \mathrm{ha} \mathrm{a}^{-}$

$130{ }^{1}$ at $\mathrm{H}+14$. Fruit weight was inversely affected than fruit set, the lowest dose had the

131 largest fruit (145 g vs $138 \mathrm{~g})$, and $\mathrm{H}+14$ had smaller fruit (132 $\mathrm{g}$ ) than when the $\mathrm{GA}_{3}$ was

132 applied at either $\mathrm{H}+7(143 \mathrm{~g})$ or $\mathrm{H}+21(149 \mathrm{~g})$. The largest fruit were for untreated control

133 trees (158 g), for $\mathrm{GA}_{3}$ at $1 \mathrm{~g} \cdot \mathrm{ha}^{-1}$ at $\mathrm{H}+7(152 \mathrm{~g})$, and for $\mathrm{GA}_{3}$ at $2 \mathrm{~g} \cdot \mathrm{ha}^{-1}$ at $\mathrm{H}+21(151 \mathrm{~g})$.

134 The smallest fruit were for $\mathrm{GA}_{3}$ at $2 \mathrm{~g} \cdot \mathrm{ha}^{-1}$ at $\mathrm{H}+14(129 \mathrm{~g}) \cdot \mathrm{GA}_{3}$ at $2 \mathrm{~g} \cdot \mathrm{ha}^{-1}$ at $\mathrm{H}+7$ had

$135135 \mathrm{~g}$ fruit on average.

136 The percentage of fruit larger than $60 \mathrm{~mm}$ and $65 \mathrm{~mm}$ was similarly affected than fruit

137 weight. The higher the dose the lower the value, whereas $\mathrm{H}+14$ had lower values than

$138 \mathrm{H}+21$. The highest percentage of fruit higher than $60 \mathrm{~mm}$ was for untreated control trees

$139(81 \%)$, followed by $\mathrm{GA}_{3}$ at $1 \mathrm{~g} \cdot \mathrm{ha}^{-1}$ at $\mathrm{H}+7$ (79\%), with no significant differences with

$140 \mathrm{GA}_{3}$ at $2 \mathrm{~g} \cdot \mathrm{ha}^{-1}$ at $\mathrm{H}+7(71 \%) \cdot \mathrm{GA}_{3}$ at either $1 \mathrm{~g} \cdot \mathrm{ha}^{-1}$ or $2 \mathrm{~g} \cdot \mathrm{ha}^{-1}$ at $\mathrm{H}+14$ had the lowest

141 values. None of the treatments statistically affected return bloom in the following year.

\section{Experiment 2}

143 The initial number of flower clusters per tree was very similar for all the trees, with no

144 significant differences among treatments (Table 4). There were no significant differences 
145 for dose and time regarding fruit set, yield, fruit weight, and return bloom when $\mathrm{GA}_{3}$ was

146 applied.

147 Fruit set was increased when $\mathrm{GA}_{4+7}+\mathrm{BA}$ was applied three times (350), and the lower

148 values were when it was applied once at $\mathrm{H}+21$ (230). The highest fruit set were when

$149 \mathrm{GA}_{4+7}+\mathrm{BA}$ was applied three times in the same season (350) and when applied at $\mathrm{H}+7$

150 (258); however, this last treatment had no significant differences with control trees (171).

151 No significant differences regarding yield were observed; however, there was a trend for

152 higher yields when $\mathrm{GA}_{4+7}+\mathrm{BA}$ was applied three times $(43 \mathrm{~kg})$ or only once at $\mathrm{H}+14(42$

$153 \mathrm{~kg})$ and $\mathrm{H}+21(41 \mathrm{~kg})$.

154 Fruit weight was significantly affected depending on the time that $\mathrm{GA}_{4+7}+\mathrm{BA}$ was

155 applied. The largest fruit were for $\mathrm{H}+14(124 \mathrm{~g})$, followed by $\mathrm{H}+21(120 \mathrm{~g}), \mathrm{H}+7$ (109

$156 \mathrm{~g})$, and the smallest fruit when it was applied three times in one season (97 $\mathrm{g})$. Control

157 trees had the largest fruit (146 g), a second group with similar fruit weight comprised all

158 the $\mathrm{GA}_{3}$ treatments and $\mathrm{GA}_{4+7}+\mathrm{BA}$ at $\mathrm{H}+14$ and $\mathrm{H}+21 . \mathrm{GA}_{4+7}+\mathrm{BA}$ at $\mathrm{H}+7$ and when

159 applied three times had the smallest fruit of all the treatments.

160 Control trees, $\mathrm{GA}_{3}$ applied two times at $1 \mathrm{~g} \cdot \mathrm{ha}^{-1}, \mathrm{GA}_{3}$ at $2 \mathrm{~g} \cdot \mathrm{ha}^{-1} \mathrm{H}+21$, and $\mathrm{GA}_{4+7}+\mathrm{BA}$

161 at $\mathrm{H}+14$ had the highest percentage of fruit larger than $60 \mathrm{~mm}$ or $65 \mathrm{~mm}$, whereas the

162 lowest values were when $\mathrm{GA}_{4+7}+\mathrm{BA}$ was applied three times at $\mathrm{H}+7, \mathrm{H}+14$, and $\mathrm{H}+21$.

163 Return bloom was not affected for any of the treatments whatsoever.

\section{Experiment 3}

165 The initial number of flower clusters per tree, fruit set, and yield were very similar for all 166 the trees, with no significant differences among treatments (Table 5). The largest fruit 167 were observed when $\mathrm{GA}_{3}$ was applied at $\mathrm{H}+14$ (128 g), followed by $\mathrm{H}+7$ (119 g), and the 168 smallest fruit for $\mathrm{H}+21(116 \mathrm{~g})$. 
$169 \mathrm{GA}_{4+7}+\mathrm{BA}$ at $\mathrm{H}+7$ had the highest percentage of fruit larger than $65 \mathrm{~mm}(32 \%)$, followed

170 by $\mathrm{H}+21(28 \%)$, and $\mathrm{H}+14$ with the lowest values (22\%). Control trees, $\mathrm{GA}_{3}$ at $2 \mathrm{~g} \cdot \mathrm{ha}^{-1}$

$171 \mathrm{H}+14$, and $\mathrm{GA}_{4+7}+\mathrm{BA}$ at $250 \mathrm{~mL} \cdot \mathrm{ha}^{-1}$ at $\mathrm{H}+7$ had the highest percentage of yield with

172 fruits larger than $65 \mathrm{~mm}(35 \%)$, whereas lower values were associated when $\mathrm{GA}_{4+7}+\mathrm{BA}$

173 was applied either at 250 or $500 \mathrm{~mL} \cdot \mathrm{ha}^{-1}$ at $\mathrm{H}+14(21 \%$ or $23 \%$, respectively). None of

174 the treatments statistically affected return bloom in the following year.

\section{Experiment 4}

176 The initial number of flower clusters per tree was very similar for all the trees, with no

177 significant differences among treatments (Table 6). For all the sites, fruit set was highest

178 when applied three times in one season. In Bellpuig, control trees had the lowest fruit set,

179 followed by $\mathrm{H}+21$, and then higher values for $\mathrm{H}+7$ an $\mathrm{H}+14$, with no significant

180 differences with $\mathrm{H}+7+14+21$. A similar pattern was observed in Castellnou de Seana,

181 with the lowest fruit set for control trees, $\mathrm{H}+7$ and $\mathrm{H}+21$. In Puigverd d'Agramunt

182 differences among treatments were less apparent. Fruit set was highest when $\mathrm{GA}_{4+7}+\mathrm{BA}$

183 was applied three times, with the lowest value for control trees. In Tornabous, there were

184 no significant differences between control trees or when $\mathrm{GA}_{4+7}+\mathrm{BA}$ was applied once at $185 \mathrm{H}+7, \mathrm{H}+14$, or $\mathrm{H}+21$.

186 Control trees had significantly less yield than $\mathrm{GA}_{4+7}+\mathrm{BA}$ applied three times in Bellpuig.

187 In Castellnou de Seana, both $\mathrm{GA}_{4+7}+\mathrm{BA}$ at $\mathrm{H}+14$ and $\mathrm{H}+7+14+21$ had higher yield than

188 control trees (25 kg and $28 \mathrm{~kg} v s 21 \mathrm{~kg}$, respectively). In Puigverd d'Agramunt, both

$189 \mathrm{GA}_{4+7}+\mathrm{BA}$ at $\mathrm{H}+7$ and $\mathrm{H}+7+14+21$ had higher yield than control trees $(21 \mathrm{~kg}$ and $23 \mathrm{~kg}$

$190 v s 14 \mathrm{~kg}$, respectively). There were no significant differences among treatments in

191 Tornabous.

192 Fruit weight was similarly affected in all four sites. Overall, the largest fruit were for

193 control trees, then there was a group comprised for $\mathrm{H}+7, \mathrm{H}+14$, and $\mathrm{H}+21$. The smallest 
194 fruit were observed when $\mathrm{GA}_{4+7}+\mathrm{BA}$ was applied three times in one season. A similar

195 pattern was observed for percentage of fruit larger than $60 \mathrm{~mm}$ or $65 \mathrm{~mm}$. The highest

196 percentage was for control trees, whereas three applications in one season had the lowest.

197 Return bloom was affected by the treatments, but it varied depending on the site. In

198 Bellpuig, the highest return bloom was for control trees, followed by one application of

$199 \mathrm{GA}_{4+7}+\mathrm{BA}$, and then when three applications were made in one season had the lowest

200 values. A similar pattern was observed in Castellnou de Seana, but with no significant 201 differences among $\mathrm{H}+7$ and $\mathrm{H}+14$ vs $\mathrm{H}+7+14+21$ in this case. In Puigverd d'Agramunt 202 return bloom for control trees was not statistically different than when one single 203 application of $\mathrm{GA}_{4+7}+\mathrm{BA}$ was done. In Tornabous, the highest return bloom was for $204 \mathrm{GA}_{4+7}+\mathrm{BA}$ at $\mathrm{H}+7$ (204), followed by control trees (182), H+21 (170), H+14 (139), and $205 \mathrm{H}+7+14+21$ with the lowest value (129).

\section{Discussion}

207 Fruit set and yield were increased when gibberellins were applied after petal fall, with a 208 positive relationship with dose. The use of gibberellins to increase fruit set has been 209 widely reported, but in most of the cases these applications are made at full bloom or right 210 after a spring frost has occurred (Costa, 2017). Sprays of $\mathrm{GA}_{3}$ and $\mathrm{GA}_{4+7}+\mathrm{BA}$ up to 4

211 days after a frost damage have been reported to increase fruit set in 'Conference' (Deckers 212 and Schoofs, 2000). In some cases, fruit set increase on 'Durondeau' and 'Conference' 213 pears has been reported when applications were even made at green cluster after a frost 214 event (Deckers and Daemen, 1996). Vercammen et al. (2015) suggested that the increase 215 in fruit set due to early applications of gibberellins is often lost at June drop. To our 216 knowledge, there are no studies that have reported use of gibberellins sprayed after petal 217 fall to increase fruit set. Yarushnykov and Blanke (2007) reported increased fruit set when 218 combined applications of $\mathrm{GA}_{3}$ and $\mathrm{GA}_{4+7}$ were done at full bloom or before, but still $25 \%$ 
219 of the fruitlets were lost during the June drop. On the other hand, Lafer (2008) did not

220 report an increase in yield when $10 \mathrm{mg} \cdot \mathrm{L}^{-1}$ of $\mathrm{GA}_{3}$ were applied at full bloom on

221 'Williams', and Vercammen and Gomand (2008) did not see any significant increase

222 when either $\mathrm{GA}_{3}$ or $\mathrm{GA}_{4+7}$ were sprayed at full bloom on 'Conference' pears. Full bloom

223 applications of $\mathrm{GA}_{4+7}+\mathrm{BA}$ did not increase fruit set on 'Garber' pears either (Silva et al.,

224 2010). Use of other hormones such as thidiazuron (TDZ) at full bloom has been reported

225 to increase fruit set in 'Packham's Triumph' pears (Pasa et al., 2017b). Furthermore,

226 application of growth regulators such as prohexadione-Ca at 2-3 weeks after full bloom

227 have been reported to increase fruit set on 'Conference' pears (Vercammen and Gomand,

228 2008). It is thought that fruit abscission in pear is stimulated by ethylene, often produced

229 in response to some type of stress (Webster, 2002). Therefore, biosynthesis ethylene

230 inhibitors could play a role in fruit set. In this regard, applications of

231 aminoethoxyvinilglycine (AVG) two weeks after full bloom were reported to increase

232 fruit set in 'Packham's Triumph' pears (Dussi et al., 2000). Pasa et al. (2017a) reported

233 that AVG sprays on 'Rocha' pears at both one and two weeks after full bloom increased

234 fruit set, but late applications after petal fall have not been reported.

235 Gibberellin sprays after petal fall did increase fruit set in our study, and these applications

236 were made in the weeks prior to the natural fruit drop or at the beginning, so that fruit

237 loss was reduced. The best results were when applied at $\mathrm{H}+14$. Applications at $\mathrm{H}+7$ had

238 similar results to those performed at $\mathrm{H}+14$, but lower fruit set and yield was observed

239 when sprays were made at $\mathrm{H}+21$. Applications of $\mathrm{GA}_{4+7}+\mathrm{BA}$ tended to have higher fruit

240 set and yield than $\mathrm{GA}_{3}$, and in addition, they were less dependent to the moment of

241 application. $\mathrm{GA}_{4+7}+\mathrm{BA}$ showed an additive effect when performing multiple applications.

242 In this sense, three sprays $(\mathrm{H}+7, \mathrm{H}+14, \mathrm{H}+21)$ doubled the fruit set when comparing to

243 control trees. The increase in fruit set with single sprays of $\mathrm{GA}_{4+7}+\mathrm{BA}$ reached a 
maximum of 124\% (Experiment 4 in Puigverd d'Agramunt), and in addition they also implied, in many cases, significant increase in yield. In the case of $\mathrm{GA}_{4+7}+\mathrm{BA}$, a maximum increase in yield of $36 \%$ was achieved (Experiment 4 in Puigverd

247 d'Agramunt), although the average was significantly lower. The fact that there were 248 higher differences in fruit set than in yield is due to the loss of fruit weight. This implies 249 that in some situations, use of gibberellins to increase fruit set may be less valuable due 250 to the reduction in fruit size. However, in most of the cases, the final economic value was higher when gibberellins after petal fall were applied. The final fruit size of pears at harvest is determined by both cell division and cell expansion within the fruits, and most cell division occurs in the first few weeks following flower fertilization, which is thought to be influenced by the relative sink strength of the fruit and the availability and efficiency of the supply of assimilates and nutrients to it (Webster, 2002). In a recent study with apple (Malus $\times$ domestica Borkh.), natural fruitlet abscission was highly correlated to the initial number of flower clusters per tree, indicating the greatest impact of flower density on carbohydrate balance (Lordan et al., 2019). All of the performed experiments in our study where within a radius $<50 \mathrm{~km}$, with no important differences in terms of climatic

260 data (data not shown). In addition, when comparing within the same location, the maximum difference that we observed among years was $\sim 2$ units for either ${ }^{\circ} \mathrm{C}$ or $\% \mathrm{RH}$ (in April when the treatments were sprayed). Therefore, it is difficult for us to evaluate how these treatments would be affected by different climate regimes, since differences

264 among years seemed more related to the initial number of flower clusters per tree than 265 weather parameters, affecting the aforementioned carbohydrate balance.

266 Gibberellins have been reported to increase sink demand in Japanese pear (Pyrus pyrifolia, cultivar 'Kousui'), which induces changes in activities of sugar metabolizing enzymes, improving fruit size (Zhang et al., 2007). In another study, Zhang et al. (2005) 
reported gibberellin applications during the rapid fruit growth period to increase carbon

270 partitioning to the fruit. In our study, when gibberellins were applied more than once in

271 one season, yield and fruit set were so high that fruit weight was significantly

272 compromised. In addition, fruit weight tended to be larger for control trees than when

273 gibberellins were applied. Therefore, in situations where fruit set and yield are increased

274 by application of hormones, irrigation and nutrition should be also improved in order to

275 not compromise fruit growth. Shackel et al. (1999) reported that water deficit by only

$27665 \%$ of evapotranspiration (ET) caused significant reductions in fruit growth. A slight

277 increase in fruit weight by nitrogen fertilization was also reported by Toselli et al. (1998).

278 Therefore, since cell expansion is mostly influenced by the availability of water to the

279 tree (Webster, 2002), significant increases in fruit set must be foreseen in order to adjust

280 the irrigation and fertilization program to maximize fruit weight.

281 In some studies, the use of gibberellins have been reported to affect fruit shape (Herrero, 1988; Vercammen et al., 2015); however, we did not see any difference when comparing 283 with control trees (data not shown). Yarushnykov and Blanke (2007) did not see

284 significant increase in abnormal fruit shape when spraying $\mathrm{GA}_{3}$ and $\mathrm{GA}_{4+7}$ on 'Alexander

285 Lucas' pears. Similarly, Deckers et al. (2000) reported good fruit shape when $\mathrm{GA}_{3}$ and $286 \mathrm{GA}_{4}$ were applied on 'Conference' pears.

287 Return bloom is another facet that needs to be taken into consideration. In our study, 288 return bloom was slightly affected when gibberellins were applied after petal fall. 289 However, return bloom was considerably reduced when doing three sprays in the same 290 season. Conversely, with the exceptions of two locations in Experiment 4, we did not see 291 significant differences with control trees in terms of return bloom when only one 292 application per season was made. Actually, the number of fruit per tree the following year 293 was similar for all the locations of Experiment 4 (data not shown). In previous studies, it 
294 has been concluded that losses in the return bloom of $20-30 \%$ do not affect the final

295 production of trees (unpublished data). Deckers and Schoofs (2000) reported that GA 3

296 severely reduced return bloom when applied at full bloom, whereas $\mathrm{GA}_{4+7}$ had less

297 negative effect. Yarushnykov and Blanke (2007) observed slightly less return bloom, but

298 differences were not significant with control trees. In another study, return bloom was not

299 affected by $\mathrm{GA}_{3}$ when applied at full bloom on 'Williams' pears (Lafer, 2008).

300 This new approach to improve fruit set in pears is still compatible with the current

301 management strategy that growers are using, so they can combine applications at bloom

302 or before with applications of gibberellins after petal fall.

303 In conclusion, the strategy that showed a better behavior to increase fruit set was

$304 \mathrm{GA}_{4+7}+\mathrm{BA}$ at $500 \mathrm{~mL} \cdot \mathrm{ha}^{-1}$ at $\mathrm{H}+14$, which coincides with the weeks prior the start of the

305 natural fruit drop or just after its start. It is worth mention to discard repeated applications

306 since they cause excessive fruit set, which can greatly reduce fruit weight. When

307 expecting important increase of fruit set, orchard management must be optimized in order

308 to reduce the loss of fruit size by increasing the number of fruit per tree. Special attention

309 should be addressed to fertigation and hand thinning to eliminate any fruit that will not

310 reach $55 \mathrm{~mm}$.

\section{Acknowledgements}

312 The authors have declared that no competing interests exist. This study was partially

313 financed by project INIA RTA03-030-C2-2 and PRODUPERA-Millora de la productivitat

314 de pera Conference', operació 01.02.01 del PDR de Catalunya 2014-2020. We thank

315 Ignasi Bros, Josep M. Torres, Marc Franquesa, Josep Anton Teixidor and Jaume Badia

316 for all the resources invested in this trial. 
Carra, B., M.S. Pasa, C.P. da Silva, C.V. do Amarante, C.A. Steffens, V.A. Bartnicki, M.N. Ciotta, P.C. Mello-Farias, and T. Einhorn. 2018. Early spring inhibition of ethylene synthesis increases fruit set and yield of 'Rocha'pear trees in Southern Brazil. Scientia Horticulturae 232, 92-96.

Ceylan, F., M.G. Akpınar, A.-M. Cherciov, B. Özkan, and M. Gül. 2018. Consumer preferences of organic products for Romania. International Journal of Agriculture, Forestry and Life Sciences 2(2), 47-55.

Çolak, A. 2018. Present condition of apple production in Usak province. International Journal of Agriculture, Forestry and Life Sciences 2(2), 189-193.

Costa, G. 2017. Bioregulators Application in Pear Production. Innovation in Fruit Growing Belgrade, Serbia.

Deckers, T. and E. Daemen. 1996. Effect of GA3, GA4/7 on fruit set and fruit quality of the pear cultivars Conference and Durondeau. Acta Horticulturae 423, 229-236.

Deckers, T., E. Daemen, and D. Vermeiren. 2000. Amelioration de la mise à fruits chez Conferénce sur des arbres jeune. Comparaison des resultats aux gibbérellins GA3 and GA4. Le Fruit Belge 483, 51-55.

Deckers, T. and H. Schoofs. 2000. Improvement of fruit set on young pear trees cultivar Conference with gibberellins. Acta Horticulturae 596, 735-743.

Deckers, T. and H. Schoofs. 2008. Status of the pear production in Europe. Acta Horticulturae 800, 95-106.

Dussi, M., D. Sosa, and G. Calvo. 2000. Effects of Retain ${ }^{\mathrm{TM}}$ on fruit maturity and fruit set of pear cultivars Williams and Packham's Triumph. Acta Horticulturae 596, 767-771.

Fleckinger, J. 1964. Le bon jardinier. La maison rustique. Paris, 362-372.

Heijerman, G., P. Roelofs, and M.J. Groot. 2015. Profitability of the Dutch growing system of 'Conference'. Acta Horticulturae 1094, 233-238.

Herrero, M. 1988. Fruit shape as a response to time of GA3 treatment in 'Agua de Aranjuez' pear. Acta Horticulturae 256, 127-132.

Iglesias, I. and E. Casals. 2013. Evolución de la producción de pera en España y análisis del mercado. Vida rural 367, 36-43.

Lafer, G. 2008. Effects of different bioregulator applications on fruit set, yield and fruit quality of 'Williams' pears. Acta Horticulturae 800, 183-187.

Lordan, J., G. Reginato, A. Lakso, P. Francescatto, and T. Robinson. 2019. Natural fruitlet abscission as related to apple tree carbon balance estimated with the MaluSim model. Scientia Horticulturae 247, 296-309.

Okatan, V., M. Polat, S. Ercisli, and M.A. Askin. 2017. Some pomological and chemical properties of local pear varieties in Usak, Turkey. SCIENTIFIC PAPERS-SERIES B-HORTICULTURE 61, 11-13.

Ozturk, G. and M.A. Askin. 2015. Various gibberellin treatments on parthenocarpic fruit development in 'Deveci' and 'Ankara' pear cultivars. Acta Horticulturae 1094, 373-382.

Pasa, M.D., B. Carra, C.P. da Silva, M.N. Ciotta, A.F. Brighenti, and A.J. Pereira. 2017a. Early spring application of Aminoethoxyvinilglycine (AVG) increases fruit set and yield of 'Rocha' pears. Revista Brasileira De Fruticultura 39(4).

Pasa, M.S., C.P. SILVA, B. Carra, A.F. Brighenti, A.L.K. SOUZA, and J.L. Petri. 2017b. Thidiazuron (TDZ) increases fruit set and yield of 'Hosui' and 'Packham's Triumph' pear trees. Anais da Academia Brasileira de Ciências 89(4), 3103-3110. 
Shackel, K., D. Ramos, L. Schwankl, E. Mitcham, S. Weinbaum, R. Snyder, W. Biasi, and G. McGourty. 1999. Effect of water and nitrogen on pear size and quality. Good Fruit Grower 50, 34-34.

Silva, J.B., A.G. Neto, D. Pazzin, J.C. Fachinello, and C.L. Giacobbo. 2010. Fruit set of pear fruits 'Garber' in the different fruiting organs regarding quadrant, pruning, girdling, bending and chemical treatments. Acta Horticulturae 872, 289-294.

Toselli, M., C. Zavalloni, B. Marangoni, M. Tagliavini, D. SCUDELLARI, and G. Andreini. 1998. Effetto dell'epoca di concimazione azotata e dei trattamenti di calcio sulla qualità delle pere conference. Frutticoltura, Bologna 9, 45-48.

Vercammen, J. 2014. Comparison of different planting systems for 'Conference'. Acta Horticulturae 1058, 37-43.

Vercammen, J. and A. Gomand. 2008. Fruit set of 'Conference': a small dose of gibberellins or Regalis. Acta Horticulturae 800, 131-138.

Vercammen, J., A. Gomand, and D. Bylemans. 2015. Improving the fruit set of 'Conference' with gibberellins or Regalis. Acta Horticulturae 1094, 257-264.

Warnier, O. 2000. Quelle est l'intérêt d'une pollinisation croisée en Conférence. Fruit Belge 484, 47-50.

Webster, A. 2002. Factors influencing the flowering, fruit set and fruit growth of European pears. Acta Horticulturae 596, 699-709.

Yarushnykov, V.V. and M.M. Blanke. 2007. Alleviation of frost damage to pear flowers by gibberellin. Acta Horticulturae 732, 659-663.

Zhang, C., K. Tanabe, F. Tamura, A. Itai, and M. Yoshida. 2007. Roles of gibberellins in increasing sink demand in Japanese pear fruit during rapid fruit growth. Plant Growth Regulation 52(2), 161-172.

Zhang, C., K. Tanabe, F. Tamura, K. Matsumoto, and A. Yoshida. 2005. 13Cphotosynthate accumulation in Japanese pear fruit during the period of rapid fruit growth is limited by the sink strength of fruit rather than by the transport capacity of the pedicel. J. Exp. Bot. 56(420), 2713-2719. 
395 Table 1. List of experiment number, year, location, and treatments performed for the 396 different fruit set trials. Note that $\mathrm{GA}_{3}$ (gibberellic acid) dose refers to active ingredient, 397 whereas for $\mathrm{GA}_{4+7}$ plus BA (Promalin ${ }^{\circledR}$ ) refers to the commercial product. Petal fall $(\mathrm{H})$ 398 (Fleckinger, 1964) plus 7, 14, or 21 days after.

\begin{tabular}{|c|c|c|c|}
\hline $\begin{array}{c}\text { Experiment } \\
\#\end{array}$ & Year & Location & Treatments \\
\hline 1 & 2010 & Gimenells & $\begin{array}{l}\mathrm{GA}_{3} 1 \mathrm{~g} \cdot \mathrm{ha}^{-1} \text { at } \mathrm{H}+7 \\
\mathrm{GA}_{3} 1 \mathrm{~g} \cdot \mathrm{ha}^{-1} \text { at } \mathrm{H}+14 \\
\mathrm{GA}_{3} 1 \mathrm{~g} \cdot \mathrm{ha}^{-1} \text { at } \mathrm{H}+21 \\
\mathrm{GA}_{3} 2 \mathrm{~g} \cdot \mathrm{ha}^{-1} \text { at } \mathrm{H}+7 \\
\mathrm{GA}_{3} 2 \mathrm{~g} \cdot \mathrm{ha}^{-1} \text { at } \mathrm{H}+14 \\
\mathrm{GA}_{3} 2 \mathrm{~g} \cdot \mathrm{ha}^{-1} \text { at } \mathrm{H}+21 \\
\text { Untreated control }\end{array}$ \\
\hline 2 & 2011 & Gimenells & $\begin{array}{l}\mathrm{GA}_{3} 2 \mathrm{~g} \cdot \mathrm{ha}^{-1} \text { at } \mathrm{H}+7 \\
\mathrm{GA}_{3} 2 \mathrm{~g} \cdot \mathrm{ha}^{-1} \text { at } \mathrm{H}+14 \\
\mathrm{GA}_{3} 2 \mathrm{~g} \cdot \mathrm{ha}^{-1} \text { at } \mathrm{H}+21 \\
\mathrm{GA}_{3} 1 \mathrm{~g} \cdot \mathrm{ha}^{-1} \text { at } \mathrm{H}+7 \& \mathrm{H}+14 \\
\mathrm{GA}_{3} 1 \mathrm{~g} \cdot \mathrm{ha}^{-1} \text { at } \mathrm{H}+14 \& \mathrm{H}+21 \\
\mathrm{GA}_{3} 2 \mathrm{~g} \cdot \mathrm{ha}^{-1} \text { at } \mathrm{H}+7 \& \mathrm{H}+14 \\
\mathrm{GA}_{3} 2 \mathrm{~g} \cdot \mathrm{ha}^{-1} \text { at } \mathrm{H}+14 \& \mathrm{H}+21 \\
\mathrm{GA}_{4+7}+\mathrm{BA} 500 \mathrm{~mL} \cdot \mathrm{ha}^{-1} \text { at } \mathrm{H}+7 \\
\mathrm{GA}_{4+7}+\mathrm{BA} 500 \mathrm{~mL} \cdot \mathrm{ha}^{-1} \text { at } \mathrm{H}+14 \\
\mathrm{GA}_{4+7}+\mathrm{BA} 500 \mathrm{~mL} \cdot \mathrm{ha}^{-1} \text { at } \mathrm{H}+21 \\
\mathrm{GA}_{4+7}+\mathrm{BA} 500 \mathrm{~mL} \cdot \mathrm{ha}^{-1} \text { at } \mathrm{H}+7, \mathrm{H}+14 \& \mathrm{H}+21 \\
\text { Untreated control }\end{array}$ \\
\hline 3 & 2012 & Gimenells & $\begin{array}{l}\mathrm{GA}_{3} 2 \mathrm{~g} \cdot \mathrm{ha}^{-1} \text { at } \mathrm{H}+7 \\
\mathrm{GA}_{3} 2 \mathrm{~g} \cdot \mathrm{ha}^{-1} \text { at } \mathrm{H}+14 \\
\mathrm{GA}_{3} 2 \mathrm{~g} \cdot \mathrm{ha}^{-1} \text { at } \mathrm{H}+21 \\
\mathrm{GA}_{4+7}+\mathrm{BA} 250 \mathrm{~mL} \cdot \mathrm{ha}^{-1} \text { at } \mathrm{H}+7 \\
\mathrm{GA}_{4+7}+\mathrm{BA} 250 \mathrm{~mL} \cdot \mathrm{ha}^{-1} \text { at } \mathrm{H}+14 \\
\mathrm{GA}_{4+7}+\mathrm{BA} 250 \mathrm{~mL} \cdot \mathrm{ha}^{-1} \text { at } \mathrm{H}+21 \\
\mathrm{GA}_{4+7}+\mathrm{BA} 500 \mathrm{~mL} \cdot \mathrm{ha}^{-1} \text { at } \mathrm{H}+7 \\
\mathrm{GA}_{4+7}+\mathrm{BA} 500 \mathrm{~mL} \cdot \mathrm{ha}^{-1} \text { at } \mathrm{H}+14 \\
\mathrm{GA}_{4+7}+\mathrm{BA} 500 \mathrm{~mL} \cdot \mathrm{ha}^{-1} \text { at } \mathrm{H}+21 \\
\text { Untreated control }\end{array}$ \\
\hline 4 & 2013 & $\begin{array}{l}\text { Tornabous, Puigverd } \\
\text { d'Agramunt, Bellpuig \& } \\
\text { Castellnou de Seana }\end{array}$ & $\begin{array}{l}\mathrm{GA}_{4+7}+\mathrm{BA} 500 \mathrm{~mL} \cdot \mathrm{ha}^{-1} \text { at } \mathrm{H}+7 \\
\mathrm{GA}_{4+7}+\mathrm{BA} 500 \mathrm{~mL} \cdot \mathrm{ha}^{-1} \text { at } \mathrm{H}+14 \\
\mathrm{GA}_{4+7}+\mathrm{BA} 500 \mathrm{~mL} \cdot \mathrm{ha}^{-1} \text { at } \mathrm{H}+21 \\
\mathrm{GA}_{4+7}+\mathrm{BA} 500 \mathrm{~mL} \cdot \mathrm{ha}^{-1} \text { at } \mathrm{H}+7, \mathrm{H}+14 \& \mathrm{H}+21 \\
\text { Untreated control }\end{array}$ \\
\hline
\end{tabular}


1 Table 2. Average monthly maximum and minimum temperature $\left({ }^{\circ} \mathrm{C}\right)$ and relative humidity (RH, \%) in 2010-2013, and mean \pm SD over all four 2 years in Gimenells, Spain.

\begin{tabular}{|c|c|c|c|c|c|c|c|c|c|c|c|c|c|c|c|}
\hline \multirow[b]{2}{*}{ Month } & \multicolumn{4}{|c|}{$\operatorname{Tmin}\left({ }^{\circ} \mathrm{C}\right)$} & \multicolumn{4}{|c|}{$\operatorname{Tmax}\left({ }^{\circ} \mathrm{C}\right)$} & \multicolumn{4}{|c|}{ RH (\%) } & \multirow{2}{*}{$\begin{array}{l}\text { Mean } \pm \text { SD } \\
\text { Tmin }\left({ }^{\circ} \mathrm{C}\right)\end{array}$} & \multirow{2}{*}{$\begin{array}{l}\text { Mean } \pm \text { SD } \\
\operatorname{Tmax}\left({ }^{\circ} \mathrm{C}\right)\end{array}$} & \multirow{2}{*}{$\begin{array}{c}\text { Mean } \pm \text { SD } \\
\text { RH (\%) }\end{array}$} \\
\hline & 2010 & 2011 & 2012 & 2013 & 2010 & 2011 & 2012 & 2013 & 2010 & 2011 & 2012 & 2013 & & & \\
\hline January & 1.5 & -0.6 & -1.0 & 0.4 & 9.2 & 8.5 & 9.9 & 10.4 & 79.2 & 84.8 & 81.8 & 80.3 & $0.1 \pm 1.1$ & $9.5 \pm 0.9$ & $81.5 \pm 2.5$ \\
\hline February & 0.6 & 1.0 & -3.4 & 0.8 & 10.9 & 14.3 & 12.4 & 12.4 & 73.2 & 73.5 & 51.9 & 68.0 & & & 10.2 \\
\hline March & 3.3 & 4.5 & 3.1 & 4.8 & 15.3 & 16.4 & 19.4 & 16.0 & 67.8 & 71.9 & 55.7 & 70.5 & & & \\
\hline April & 7.1 & 8.6 & 6.8 & 6.2 & 20.2 & 23.4 & 18.8 & 18.9 & 67.4 & 66.3 & 62.9 & 65.3 & & & \\
\hline May & 9.5 & 11.4 & 11.6 & 7.7 & 22.9 & 26.9 & 26.3 & 20.5 & 61.0 & 62.0 & 59.1 & 65.7 & & & \\
\hline June & 13.6 & 14.3 & 15.5 & 12.4 & 28.0 & 28.7 & 31.2 & 27.2 & 62.1 & 57.7 & 52.5 & 59.0 & & & \\
\hline July & 18.2 & 16.0 & 16.3 & 17.7 & 33.5 & 30.2 & 31.3 & 32.7 & 54.3 & 55.8 & 56.5 & 58.4 & & & \\
\hline Augi & 16.2 & 17.6 & 18.3 & 16.5 & 31.3 & 32.5 & 33.8 & 30.2 & 58.0 & 58.5 & 54.8 & 63.1 & & & \\
\hline Sept & 13.0 & 14.2 & 13.1 & 12.8 & 26.5 & 29.8 & 27.2 & 27.5 & 65.6 & 63.2 & 63.5 & 65.6 & 0.6 & 1.4 & 1.3 \\
\hline Octok & 8.0 & 9.1 & 9.7 & 10.5 & 20.8 & 23.3 & 22.1 & 23.8 & 70.3 & 69.1 & 75.3 & 70.6 & 1.1 & $22.5 \pm 1.4$ & 2.7 \\
\hline Nove & 0 & 8.0 & 4.9 & 4.2 & 14.2 & 15.5 & 14.4 & 14.9 & 75.4 & 86.0 & 83.1 & 69.9 & & $14.7 \pm 0.6$ & $78.6=$ \\
\hline December & -0.2 & 1.6 & 0.8 & -0.4 & 9.2 & 11.3 & 11.3 & 7.4 & 76.5 & 80.2 & 80.2 & 87.3 & $0.5 \pm 0.9$ & $9.8 \pm 1.9$ & $81.1 \pm 4.5$ \\
\hline
\end{tabular}


Table 3. Number of flower clusters per tree (Flower \#), fruit set (final fruit number/flower cluster), yield (kg/tree), fruit weight (g), percentage of 6 yield $>60 \mathrm{~mm}$, percentage of yield $>65 \mathrm{~mm}$, and return bloom for each combination of $\mathrm{GA}_{3}$ dose and time (7, 14, or 21 days after petal fall) on 7 'Conference' pear trees (Experiment 1). Note that $\mathrm{GA}_{3}$ (gibberellic acid) dose refers to active ingredient $\left(1 \mathrm{~g} \cdot \mathrm{ha}^{-1} \mathrm{or} 2 \mathrm{~g} \cdot \mathrm{ha} \mathrm{H}^{-1}\right)$. Petal fall $(\mathrm{H})$ 8 (Fleckinger, 1964). Return bloom was measured the following spring, by counting the total number of flower clusters per tree. Grey bars represent 9 variable value. Means within a column followed by different letters denotes significant differences among treatments (Tukey's honestly significant 10 difference, $P \leq 0.05)$. NS Nonsignificant at $P \leq 0.05$.

\begin{tabular}{|c|c|c|c|c|c|c|c|c|c|c|}
\hline Hormone & Dose & Time & Treatment & Flower \# & Fruit set & Yield (kg) & $\begin{array}{c}\text { Fruit weight } \\
(\mathrm{g})\end{array}$ & $\begin{array}{c}\text { Yield }>60 \mathrm{~mm} \\
(\%)\end{array}$ & $\begin{array}{c}\text { Yield }>65 \mathrm{~mm} \\
(\%)\end{array}$ & $\begin{array}{c}\text { Return } \\
\text { bloom }\end{array}$ \\
\hline \multirow[t]{15}{*}{$\mathrm{GA}_{3}$} & $1 \mathrm{~g}$ & & & 336 & $48 \mathrm{~B}$ & $22 \mathrm{~B}$ & $145 \mathrm{~A}$ & $75 \mathrm{~A}$ & 55 & 175 \\
\hline & $2 \mathrm{~g}$ & & & 342 & $56 \mathrm{~A}$ & $26 \mathrm{~A}$ & $138 \mathrm{~B}$ & $71 \mathrm{~B}$ & 50 & 168 \\
\hline & $P$ & & & NS & 0.0071 & 0.0161 & 0.0386 & 0.0208 & NS & NS \\
\hline & & $\mathrm{H}+7$ & & 339 & $52 \mathrm{~B}$ & $24 \mathrm{~A}$ & $143 \mathrm{~A}$ & $75 \mathrm{~A}$ & $54 \mathrm{AB}$ & 136 \\
\hline & & $\mathrm{H}+14$ & & 338 & $64 \mathrm{~A}$ & $27 \mathrm{~A}$ & 132 B & $67 \mathrm{~B}$ & $46 \mathrm{~B}$ & 163 \\
\hline & & $\mathrm{H}+21$ & & 340 & $41 \mathrm{C}$ & $20 \mathrm{~B}$ & $149 \mathrm{~A}$ & $77 \mathrm{~A}$ & $57 \mathrm{~A}$ & 215 \\
\hline & & $P$ & & NS & $<0.0001$ & 0.0005 & $<0.0001$ & $<0.0001$ & 0.0048 & NS \\
\hline & & & Control & 349 & $40 \mathrm{C}$ & $21 \mathrm{~B}$ & $158 \mathrm{~A}$ & $81 \mathrm{~A}$ & $64 \mathrm{~A}$ & 193 \\
\hline & & & $\mathrm{GA}_{3} 1 \mathrm{~g}$ at $\mathrm{H}+7$ & 335 & $44 \mathrm{BC}$ & $22 B$ & $152 \mathrm{AB}$ & $79 \mathrm{~A}$ & $61 \mathrm{AB}$ & 138 \\
\hline & & & $\mathrm{GA}_{3} 1 \mathrm{~g}$ at $\mathrm{H}+14$ & 338 & $58 \mathrm{AB}$ & $25 \mathrm{AB}$ & $135 \mathrm{BC}$ & $69 \mathrm{BC}$ & 48 BCD & 182 \\
\hline & & & $\mathrm{GA}_{3} 1 \mathrm{~g}$ at $\mathrm{H}+21$ & 337 & $42 \mathrm{C}$ & $20 \mathrm{~B}$ & $147 \mathrm{AB}$ & $77 \mathrm{AB}$ & $55 \mathrm{ABCD}$ & 204 \\
\hline & & & $\mathrm{GA}_{3} 2 \mathrm{~g}$ at $\mathrm{H}+7$ & 345 & $60 \mathrm{~A}$ & $27 \mathrm{AB}$ & $135 \mathrm{BC}$ & $71 \mathrm{ABC}$ & $46 \mathrm{CD}$ & 132 \\
\hline & & & $\mathrm{GA}_{3} 2 \mathrm{~g}$ at $\mathrm{H}+14$ & 339 & $69 \mathrm{~A}$ & $30 \mathrm{~A}$ & $129 \mathrm{C}$ & $64 \mathrm{C}$ & $45 \mathrm{D}$ & 144 \\
\hline & & & $\mathrm{GA}_{3} 2 \mathrm{~g}$ at $\mathrm{H}+21$ & 344 & $40 \mathrm{C}$ & $20 \mathrm{~B}$ & $151 \mathrm{AB}$ & $77 \mathrm{AB}$ & $59 \mathrm{ABC}$ & 226 \\
\hline & & & $P$ & NS & $<0.0001$ & 0.0003 & $<0.0001$ & $<0.0001$ & 0.0002 & NS \\
\hline
\end{tabular}


1 Table 4. Number of flower clusters per tree (Flower \#), fruit set (final fruit number/flower

2 cluster), yield ( $\mathrm{kg} /$ tree), fruit weight $(\mathrm{g})$, percentage of yield $>60 \mathrm{~mm}$, percentage of yield

$3>65 \mathrm{~mm}$, and return bloom for each combination of $\mathrm{GA}_{3}$ or $\mathrm{GA}_{4+7}+\mathrm{BA}$ dose and time

$4(7,14$, or 21 days after petal fall) on 'Conference' pear trees (Experiment 2). Note that

$5 \mathrm{GA}_{3}$ (gibberellic acid) dose refers to active ingredient $\left(1 \mathrm{~g} \cdot \mathrm{ha}^{-1}\right.$ or $\left.2 \mathrm{~g} \cdot \mathrm{ha}^{-1}\right)$, whereas for

$6 \mathrm{GA}_{4+7}+\mathrm{BA}\left(\right.$ Promalin $\left.^{\circledR}\right)$ refers to the commercial product $\left(500 \mathrm{~mL} \cdot \mathrm{ha}^{-1}\right)$. Petal fall $(\mathrm{H})$

7 (Fleckinger, 1964). Return bloom was measured the following spring, by counting the

8 total number of flower clusters per tree. Grey bars represent variable value. Means within

9 a column followed by different letters denotes significant differences among treatments

10 (Tukey's honestly significant difference, $P \leq 0.05)$. ${ }^{\text {NS }}$ Nonsignificant at $P \leq 0.05$.

\begin{tabular}{|c|c|c|c|c|c|c|c|c|c|c|}
\hline Hormone & Dose & Time & Treatment & Flower \# & Fruit set & Yield (kg) & $\begin{array}{c}\text { Fruit weight } \\
\text { (g) }\end{array}$ & $\begin{array}{c}\text { Yield }>60 \mathrm{~mm} \\
(\%)\end{array}$ & $\begin{array}{c}\text { Yield }>65 \mathrm{~mm} \\
(\%)\end{array}$ & $\begin{array}{l}\text { Return } \\
\text { bloom }\end{array}$ \\
\hline \multirow[t]{12}{*}{$\mathrm{GA}_{3}$} & $1 \mathrm{~g}$ & & & 143 & 206 & 36 & 123 & 60 & 36 & 113 \\
\hline & $2 g$ & & & 137 & 223 & 36 & 120 & 58 & 33 & 122 \\
\hline & $P$ & & & NS & NS & NS & NS & NS & NS & NS \\
\hline & $1 \mathrm{~g}$ & $\mathrm{H}+7 \& \mathrm{H}+14$ & & 141 & 216 & 37 & 123 & 59 & 36 & 110 \\
\hline & & $\mathrm{H}+14 \& \mathrm{H}+21$ & & 144 & 197 & 34 & 122 & 60 & 36 & 116 \\
\hline & & $P$ & & NS & NS & NS & NS & NS & NS & NS \\
\hline & $2 \mathrm{~g}$ & $\overline{\mathrm{H}+7}$ & & 138 & 230 & 37 & 119 & 55 & 33 & 122 \\
\hline & & $\mathrm{H}+14$ & & 140 & 232 & 38 & 118 & 54 & 30 & 135 \\
\hline & & $\mathrm{H}+21$ & & 138 & 211 & 34 & 126 & 60 & 34 & 134 \\
\hline & & $\mathrm{H}+7 \& \mathrm{H}+14$ & & 137 & 230 & 37 & 115 & 53 & 29 & 145 \\
\hline & & $H+14 \& H+21$ & & 137 & 208 & 35 & 124 & 61 & 37 & 102 \\
\hline & & $P$ & & NS & NS & NS & NS & NS & NS & NS \\
\hline \multirow[t]{18}{*}{$\mathrm{GA}_{4+7}+\mathrm{BA}$} & $500 \mathrm{~mL}$ & $\overline{\mathrm{H}+7}$ & & 139 & $258 \mathrm{AB}$ & 37 & $109 \mathrm{BC}$ & $50 \mathrm{~A}$ & $27 \mathrm{AB}$ & 133 \\
\hline & & $\mathrm{H}+14$ & & 140 & $251 \mathrm{AB}$ & 42 & $124 \mathrm{~A}$ & $60 \mathrm{~A}$ & $37 \mathrm{~A}$ & 123 \\
\hline & & $\mathrm{H}+21$ & & 150 & $230 \mathrm{~B}$ & 41 & $120 \mathrm{AB}$ & $56 \mathrm{~A}$ & $31 \mathrm{~A}$ & 111 \\
\hline & & $H+7 \& H+14 \& H+21$ & & 135 & $350 \mathrm{~A}$ & 43 & $97 \mathrm{C}$ & $35 \mathrm{~B}$ & $16 \mathrm{~B}$ & 90 \\
\hline & & $P$ & & NS & 0.0107 & NS & 0.0001 & 0.0001 & 0.0022 & NS \\
\hline & & & Control & 138 & $171 \mathrm{~B}$ & $34 \mathrm{~A}$ & $146 \mathrm{~A}$ & $72 \mathrm{~A}$ & $47 \mathrm{~A}$ & 113 \\
\hline & & & $\mathrm{GA}_{3} 1 \mathrm{~g}$ at $\mathrm{H}+7 \& \mathrm{H}+14$ & 141 & $216 \mathrm{~B}$ & $37 \mathrm{~A}$ & $123 \mathrm{BC}$ & $59 \mathrm{AB}$ & $36 \mathrm{AB}$ & 110 \\
\hline & & & $\mathrm{GA}_{3} 1 \mathrm{~g}$ at $\mathrm{H}+14 \& \mathrm{H}+21$ & 144 & $197 \mathrm{~B}$ & $34 \mathrm{~A}$ & $122 \mathrm{BC}$ & $60 \mathrm{AB}$ & $36 \mathrm{AB}$ & 116 \\
\hline & & & $\mathrm{GA}_{3} 2 \mathrm{~g}$ at $\mathrm{H}+7$ & 138 & $230 \mathrm{~B}$ & $37 \mathrm{~A}$ & $119 \mathrm{BC}$ & $55 \mathrm{~B}$ & $33 A B$ & 122 \\
\hline & & & $\mathrm{GA}_{3} 2 \mathrm{~g}$ at $\mathrm{H}+14$ & 140 & $232 \mathrm{~B}$ & $38 \mathrm{~A}$ & $118 \mathrm{BC}$ & $54 \mathrm{~B}$ & $30 \mathrm{BC}$ & 135 \\
\hline & & & $\mathrm{GA}_{3} 2 \mathrm{~g}$ at $\mathrm{H}+21$ & 138 & $211 \mathrm{~B}$ & $34 \mathrm{~A}$ & $126 \mathrm{~B}$ & $60 \mathrm{AB}$ & $34 \mathrm{AB}$ & 134 \\
\hline & & & $\mathrm{GA}_{3} 2 \mathrm{~g}$ at $\mathrm{H}+7 \& \mathrm{H}+14$ & 138 & $236 \mathrm{~B}$ & $37 \mathrm{~A}$ & $115 \mathrm{BC}$ & $54 \mathrm{~B}$ & $29 B C$ & 145 \\
\hline & & & $\mathrm{GA}_{3} 2 \mathrm{~g}$ at $\mathrm{H}+14 \& \mathrm{H}+21$ & 137 & $208 \mathrm{~B}$ & $35 \mathrm{~A}$ & $124 \mathrm{BC}$ & $61 \mathrm{AB}$ & $37 \mathrm{AB}$ & 102 \\
\hline & & & $\mathrm{GA}_{4+7}+\mathrm{BA} 500 \mathrm{~mL}$ at $\mathrm{H}+7$ & 139 & $258 \mathrm{AB}$ & $37 \mathrm{~A}$ & $109 \mathrm{CD}$ & $50 \mathrm{~B}$ & $27 \mathrm{BC}$ & 133 \\
\hline & & & $\mathrm{GA}_{4+7}+\mathrm{BA} 500 \mathrm{~mL}$ at $\mathrm{H}+14$ & 140 & $250 \mathrm{~B}$ & $42 \mathrm{~A}$ & $124 \mathrm{BC}$ & $60 A B$ & $36 \mathrm{AB}$ & 124 \\
\hline & & & $\mathrm{GA}_{4+7}+\mathrm{BA} 500 \mathrm{~mL}$ at $\mathrm{H}+21$ & 150 & $230 \mathrm{~B}$ & $41 \mathrm{~A}$ & $120 \mathrm{BC}$ & $56 \mathrm{~B}$ & $31 \mathrm{ABC}$ & 111 \\
\hline & & & $\mathrm{GA}_{4+7}+\mathrm{BA} 500 \mathrm{~mL}$ at $\mathrm{H}+7 \& \mathrm{H}+14 \& \mathrm{H}+21$ & 135 & $350 \mathrm{~A}$ & $43 \mathrm{~A}$ & $97 \mathrm{D}$ & $35 \mathrm{C}$ & $16 \mathrm{C}$ & 90 \\
\hline & & & $P$ & NS & $<0.0001$ & 0.027 & $<0.0001$ & $<0.0001$ & $<0.0001$ & NS \\
\hline
\end{tabular}


1 Table 5. Number of flower clusters per tree (Flower \#), fruit set (final fruit number/flower cluster), yield (kg/tree), fruit weight (g), percentage of

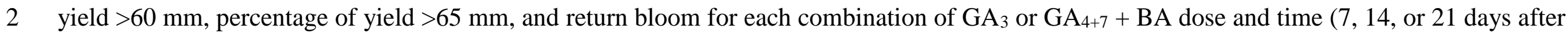
3 petal fall) on 'Conference' pear trees (Experiment 3). Note that $\mathrm{GA}_{3}$ (gibberellic acid) dose refers to active ingredient ( $\left.2 \mathrm{~g} \cdot \mathrm{ha}^{-1}\right)$, whereas for GA $4+7$ 4 + BA (Promalin ${ }^{\circledR}$ ) refers to the commercial product $\left(250 \mathrm{~mL} \cdot \mathrm{ha}^{-1}\right.$ or $\left.500 \mathrm{~mL} \cdot \mathrm{ha}^{-1}\right)$. Petal fall (H) (Fleckinger, 1964). Return bloom was measured 5 the following spring, by counting the total number of flower clusters per tree. Grey bars represent variable value. Means within a column followed 6 by different letters denotes significant differences among treatments (Tukey's honestly significant difference, $P \leq 0.05$ ). ${ }^{\mathrm{NS}}$ Nonsignificant at $7 \quad P \leq 0.05$.

\begin{tabular}{|c|c|c|c|c|c|c|c|c|c|c|}
\hline Hormone & Dose & Time & Treatment & Flower \# & Fruit set & Yield (kg) & $\begin{array}{l}\text { Fruit weight } \\
\text { (g) }\end{array}$ & $\begin{array}{c}\text { Yield }>60 \mathrm{~mm} \\
(\%)\end{array}$ & $\begin{array}{c}\text { Yield >65 mm } \\
(\%) \\
\end{array}$ & $\begin{array}{l}\text { Return } \\
\text { bloom }\end{array}$ \\
\hline \multirow[t]{4}{*}{$\mathrm{GA}_{3}$} & $2 g$ & $\mathrm{H}+7$ & & 131 & 161 & 24 & $119 \mathrm{AB}$ & 51 & 29 & 294 \\
\hline & & $\mathrm{H}+14$ & & 132 & 143 & 24 & $128 \mathrm{~A}$ & 58 & 35 & 252 \\
\hline & & $\mathrm{H}+21$ & & 130 & 140 & 21 & $116 \mathrm{~B}$ & 48 & 26 & 283 \\
\hline & & $P$ & & NS & NS & NS & 0.0476 & NS & NS & NS \\
\hline \multirow[t]{18}{*}{$\mathrm{GA}_{4+7}+\mathrm{BA}$} & $250 \mathrm{~mL}$ & & & 131 & 144 & 22 & 123 & 52 & 29 & 250 \\
\hline & $500 \mathrm{~mL}$ & & & 128 & 158 & 23 & 120 & 51 & 26 & 264 \\
\hline & $P$ & & & NS & NS & NS & NS & NS & NS & NS \\
\hline & & $\mathrm{H}+7$ & & 130 & 143 & 22 & 127 & 56 & $32 \mathrm{~A}$ & 255 \\
\hline & & $\mathrm{H}+14$ & & 129 & 160 & 22 & 115 & 46 & 22 B & 235 \\
\hline & & $\mathrm{H}+21$ & & 130 & 151 & 23 & 123 & 52 & $28 \mathrm{AB}$ & 281 \\
\hline & & $P$ & & NS & NS & NS & NS & NS & 0.0413 & NS \\
\hline & & & Control & 127 & 133 & 21 & $131 \mathrm{~A}$ & 60 & $35 \mathrm{~A}$ & 270 \\
\hline & & & $\mathrm{GA}_{3} 2 \mathrm{~g}$ at $\mathrm{H}+7$ & 130 & 161 & 24 & $119 \mathrm{~A}$ & 51 & $29 \mathrm{~A}$ & 295 \\
\hline & & & $\mathrm{GA}_{3} 2 \mathrm{~g}$ at $\mathrm{H}+14$ & 132 & 143 & 24 & $128 \mathrm{~A}$ & 58 & $35 \mathrm{~A}$ & 254 \\
\hline & & & $\mathrm{GA}_{3} 2 \mathrm{~g}$ at $\mathrm{H}+21$ & 129 & 140 & 20 & $116 \mathrm{~A}$ & 48 & $26 \mathrm{~A}$ & 284 \\
\hline & & & $\mathrm{GA}_{4+7}+\mathrm{BA} 250 \mathrm{~mL}$ at $\mathrm{H}+7$ & 131 & 122 & 20 & $131 \mathrm{~A}$ & 60 & $35 \mathrm{~A}$ & 264 \\
\hline & & & $\mathrm{GA}_{4+7}+\mathrm{BA} 250 \mathrm{~mL}$ at $\mathrm{H}+14$ & 130 & 160 & 22 & $113 \mathrm{~A}$ & 44 & $21 \mathrm{~A}$ & 241 \\
\hline & & & $\mathrm{GA}_{4+7}+\mathrm{BA} 250 \mathrm{~mL}$ at $\mathrm{H}+21$ & 131 & 145 & 22 & $124 \mathrm{~A}$ & 52 & $30 \mathrm{~A}$ & 252 \\
\hline & & & $\mathrm{GA}_{4+7}+\mathrm{BA} 500 \mathrm{~mL}$ at $\mathrm{H}+7$ & 127 & 163 & 24 & $122 \mathrm{~A}$ & 53 & $29 \mathrm{~A}$ & 254 \\
\hline & & & $\mathrm{GA}_{4+7}+\mathrm{BA} 500 \mathrm{~mL}$ at $\mathrm{H}+14$ & 128 & 154 & 22 & $117 \mathrm{~A}$ & 48 & $23 \mathrm{~A}$ & 233 \\
\hline & & & $\mathrm{GA}_{4+7}+\mathrm{BA} 500 \mathrm{~mL}$ at $\mathrm{H}+21$ & 128 & 157 & 24 & $121 \mathrm{~A}$ & 51 & $27 \mathrm{~A}$ & 317 \\
\hline & & & $P$ & NS & NS & NS & 0.0355 & NS & 0.0494 & NS \\
\hline
\end{tabular}


9 Table 6. Number of flower clusters per tree (Flower \#), fruit set (final fruit number/flower cluster), yield (kg/tree), fruit weight (g), percentage of 10 yield $>60 \mathrm{~mm}$, percentage of yield $>65 \mathrm{~mm}$, and return bloom for each combination of $\mathrm{GA}_{4+7}+\mathrm{BA}$ applied at $500 \mathrm{~mL} \cdot \mathrm{ha}^{-1}$ of commercial product 11 (Promalin $\left.^{\circledR}\right)$ at 7, 14, or 21 days after petal fall (H) (Fleckinger, 1964) on 'Conference' pear trees in four different sites (Experiment 4). Return 12 bloom was measured the following spring, by counting the total number of flower clusters per tree. Grey bars represent variable value. Means 13 within a column followed by different letters denotes significant differences among treatments (Tukey's honestly significant difference, $P \leq 0.05$ ).

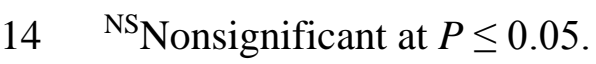

\begin{tabular}{|c|c|c|c|c|c|c|c|c|}
\hline Site & Treatment & Flower \# & Fruit set & Yield (kg) & Fruit weight $(g)$ & $\begin{array}{c}\text { Yield >60 mm } \\
(\%)\end{array}$ & $\begin{array}{c}\text { Yield >65 mm } \\
(\%)\end{array}$ & Return bloom \\
\hline \multirow[t]{6}{*}{ Bellpuig } & Control & 397 & $35 \mathrm{C}$ & $21 \mathrm{~B}$ & $158 \mathrm{~A}$ & $84 \mathrm{~A}$ & \begin{tabular}{l|l}
$\mathrm{A}$ \\
\end{tabular} & \begin{tabular}{l|l}
$250 \mathrm{~A}$ \\
\end{tabular} \\
\hline & $\mathrm{GA}_{4+7}+\mathrm{BA}$ at $\mathrm{H}+7$ & 393 & $66 \mathrm{AB}$ & $26 \mathrm{AB}$ & $103 \mathrm{~B}$ & $44 \mathrm{~B}$ & $22 \mathrm{~B}$ & 167 B \\
\hline & $\mathrm{GA}_{4+7}+\mathrm{BA}$ at $\mathrm{H}+14$ & 420 & $66 \mathrm{AB}$ & $27 \mathrm{AB}$ & $99 \mathrm{~B}$ & $37 \mathrm{~B}$ & $16 \mathrm{~B}$ & $140 \mathrm{~B}$ \\
\hline & $\mathrm{GA}_{4+7}+\mathrm{BA}$ at $\mathrm{H}+21$ & 409 & $61 \mathrm{~B}$ & $26 \mathrm{AB}$ & $109 \mathrm{~B}$ & $46 \mathrm{~B}$ & $23 \mathrm{~B}$ & $165 \mathrm{~B}$ \\
\hline & $\mathrm{GA}_{4+7}+\mathrm{BA}$ at $\mathrm{H}+7 \& \mathrm{H}+14 \& \mathrm{H}+21$ & 414 & $91 \mathrm{~A}$ & $28 \mathrm{~A}$ & $78 \mathrm{C}$ & $15 \mathrm{C}$ & $5 \mathrm{C}$ & $71 \mathrm{C}$ \\
\hline & $P$ & NS & $<0.0001$ & 0.0334 & $<0.0001$ & $<0.0001$ & $<0.0001$ & $<0.0001$ \\
\hline Castellnou & Control & 313 & $46 \mathrm{C}$ & $21 \mathrm{C}$ & $150 \mathrm{~A}$ & $80 \mathrm{~A}$ & $59 \mathrm{~A}$ & $181 \mathrm{~A}$ \\
\hline \multirow[t]{5}{*}{ de Seana } & $\mathrm{GA}_{4+7}+\mathrm{BA}$ at $\mathrm{H}+7$ & 301 & $73 \mathrm{BC}$ & $23 \mathrm{BC}$ & $109 \mathrm{~B}$ & $50 \mathrm{~B}$ & $28 \mathrm{~B}$ & $114 \mathrm{BC}$ \\
\hline & $\mathrm{GA}_{4+7}+\mathrm{BA}$ at $\mathrm{H}+14$ & 290 & $89 \mathrm{AB}$ & $25 \mathrm{AB}$ & $101 \mathrm{~B}$ & $39 \mathrm{~B}$ & $20 \mathrm{BC}$ & $113 \mathrm{BC}$ \\
\hline & $\mathrm{GA}_{4+7}+\mathrm{BA}$ at $\mathrm{H}+21$ & 345 & $69 \mathrm{BC}$ & $24 \mathrm{BC}$ & $105 \mathrm{~B}$ & $41 \mathrm{~B}$ & $20 \mathrm{~B}$ & $130 \mathrm{~B}$ \\
\hline & $\mathrm{GA}_{4+7}+\mathrm{BA}$ at $\mathrm{H}+7 \& \mathrm{H}+14 \& \mathrm{H}+21$ & 304 & $115 \mathrm{~A}$ & $28 \mathrm{~A}$ & $83 \mathrm{C}$ & $19 \mathrm{C}$ & $7 \mathrm{C}$ & $83 \mathrm{C}$ \\
\hline & $\begin{array}{c}P \\
\end{array}$ & NS & $<0.0001$ & 0.0009 & $<0.0001$ & $<0.0001$ & $<0.0001$ & $<0.0001$ \\
\hline Puigverd & Control & 377 & $29 \mathrm{C}$ & $14 \mathrm{~B}$ & $139 \mathrm{~A}$ & $72 \mathrm{~A}$ & $47 \mathrm{~A}$ & $195 \mathrm{~A}$ \\
\hline \multirow[t]{5}{*}{ d'Agramunt } & $\mathrm{GA}_{4+7}+\mathrm{BA}$ at $\mathrm{H}+7$ & 358 & $69 \mathrm{~B}$ & $21 \mathrm{~A}$ & $90 \mathrm{~B}$ & $25 \mathrm{~B}$ & $7 \mathrm{~B}$ & $148 \mathrm{AB}$ \\
\hline & $\mathrm{GA}_{4+7}+\mathrm{BA}$ at $\mathrm{H}+14$ & 366 & $65 \mathrm{~B}$ & $19 \mathrm{AB}$ & $82 \mathrm{BC}$ & $15 \mathrm{BC}$ & $4 \mathrm{~B}$ & $127 \mathrm{AB}$ \\
\hline & $\mathrm{GA}_{4+7}+\mathrm{BA}$ at $\mathrm{H}+21$ & 383 & $61 \mathrm{~B}$ & $19 \mathrm{AB}$ & $84 \mathrm{~B}$ & $17 \mathrm{~B}$ & $5 \mathrm{~B}$ & $147 \mathrm{AB}$ \\
\hline & $\mathrm{GA}_{4+7}+\mathrm{BA}$ at $\mathrm{H}+7 \& \mathrm{H}+14$ \& $\mathrm{H}+21$ & 373 & $94 \mathrm{~A}$ & $23 \mathrm{~A}$ & $67 \mathrm{C}$ & $3 c$ & $0 \mathrm{~B}$ & $78 \mathrm{~B}$ \\
\hline & $P$ & NS & $<0.0001$ & 0.0018 & $<0.0001$ & $<0.0001$ & $<0.0001$ & $<0.0001$ \\
\hline \multirow[t]{6}{*}{ Tornabous } & Control & 388 & $39 \mathrm{~B}$ & 21 & $140 \mathrm{~A}$ & $73 \mathrm{~A}$ & $55 \mathrm{~A}$ & $182 \mathrm{AB}$ \\
\hline & $\mathrm{GA}_{4+7}+\mathrm{BA}$ at $\mathrm{H}+7$ & 388 & $50 \mathrm{~B}$ & 21 & $109 \mathrm{BC}$ & $47 \mathrm{~B}$ & $28 \mathrm{~B}$ & $204 \mathrm{~A}$ \\
\hline & $\mathrm{GA}_{4+7}+\mathrm{BA}$ at $\mathrm{H}+14$ & 375 & $57 \mathrm{AB}$ & 23 & $108 \mathrm{BC}$ & $45 \mathrm{~B}$ & $26 \mathrm{~B}$ & $139 \mathrm{AB}$ \\
\hline & $\mathrm{GA}_{4+7}+\mathrm{BA}$ at $\mathrm{H}+21$ & 398 & $50 \mathrm{~B}$ & 22 & $113 \mathrm{~B}$ & $47 \mathrm{~B}$ & $27 \mathrm{~B}$ & $170 \mathrm{AB}$ \\
\hline & $\mathrm{GA}_{4+7}+\mathrm{BA}$ at $\mathrm{H}+7 \& \mathrm{H}+14 \& \mathrm{H}+21$ & 385 & $76 \mathrm{~A}$ & 26 & $95 \mathrm{C}$ & $27 \mathrm{C}$ & $12 \mathrm{C}$ & $129 \mathrm{~B}$ \\
\hline & $P$ & NS & 0.0009 & NS & $<0.0001$ & $<0.0001$ & $<0.0001$ & 0.0140 \\
\hline
\end{tabular}

